\title{
Influence of Different Protecting Groups on the Regioselectivity of the Hydrotelluration Reaction of Hydroxy Alkynes
}

\author{
Juliana M. Oliveira, ${ }^{a}$ Dayvson J. Palmeira, ${ }^{a}$ João V. Comasseto ${ }^{b}$ and Paulo H. Menezes ${ }^{*, a}$ \\ ${ }^{a}$ Departamento de Química Fundamental, Universidade Federal de Pernambuco, CCEN, UFPE, \\ Av. Prof. Luiz Freire, s/n, 50670-901 Recife-PE, Brazil \\ ${ }^{b}$ Instituto de Química, Universidade de São Paulo, USP, Av. Prof. Lineu Prestes, 748, \\ 05508-900 São Paulo-SP, Brazil
}

\begin{abstract}
A influência de grupos protetores na síntese régio- e estereosseletiva de teluretos vinílicos preparados a partir de BuTeNa e álcoois propargílicos e homopropargílicos demonstrou que o eter de silício TIPS é útil como grupo régio-dirigente. A aplicação da metodologia na síntese de um fragmento do ( \pm )-Seselidiol, um produto natural, demonstrou a aplicabilidade da metodologia desenvolvida.
\end{abstract}

The influence of protecting groups on the synthesis of regio- and stereodefined vinyl tellurides derived from the reaction of BuTeNa and propargylic- or homo-propargylic alcohols showed that TIPS silyl ether is useful as a regiodirecting group. The application of the methodology to the synthesis of a fragment of $( \pm)$-Seselidiol, a natural product, demonstrated the applicability of the new methodology.

Keywords: hydrotelluration, alkynes, seselidiol, regioselectivity

\section{Introduction}

The hydrometalation of alkynes is a common method for the preparation of functionalized alkenes. Usually, the reaction proceeds in a syn fashion to yield the corresponding $E$-alkene via a four-membered ring concerted mechanism. ${ }^{1}$

The hydrotelluration reaction differs from the other hydrometalations, since it proceeds by an anti addition leading to the corresponding $Z$-vinyl telluride, which is stereochemically stable, since no isomerization to the $E$ isomer has been reported to date. ${ }^{2}$ This characteristic makes the hydrotelluration reaction a very important method for the generation of $Z$-alkenes (starting from alkynes), which are not easily accessible by other methodologies.

Allylic alcohols containing a stereodefined double bond are important synthetic intermediates. ${ }^{3}$ These compounds can be easily prepared when hydroxylalkynes are subjected to hydrotelluration conditions. The $Z$-isomer is usually obtained in good yields together with the corresponding regioisomer. These, can be separated by column chromatography. Early studies dealing with

\footnotetext{
*e-mail: pmenezes@ufpe.br
}

the influence of the structure of the hydroxyl alkyne on the regioselectivity of the reaction were performed and different regioisomeric ratios were obtained. ${ }^{4}$ Later, Comasseto and co-workers ${ }^{5}$ have studied the influence of some protective groups in the reaction.

\section{Results and Discussion}

We describe herein the results obtained in the hydrotelluration reaction of protected propargylic and homo-propargylic alcohols. In an initial approach propargyl alcohol $\mathbf{1}$ was converted into its TBS, ${ }^{6} \mathbf{2}$; TIPS, ${ }^{7} \mathbf{3}$; TBPS, ${ }^{8}$ 4; MEM, ${ }^{9}$ 5; and THP, ${ }^{10} 6$ derivatives according to literature procedures. All compounds were obtained in good yields and purified by distillation. Compounds 1-6 were then subjected to hydrotelluration conditions ${ }^{11}$ to yield the corresponding regioisomeric vinyl tellurides $\mathbf{A}$ and $\mathbf{B}$.

The regioisomeric ratio was determined by ${ }^{1} \mathrm{H}$ NMR and confirmed by ${ }^{125} \mathrm{Te}$ NMR and gas chromatography as shown on Figure 1.

The obtained results are shown on Table 1 . When 1 was used as the alkyne source an almost 1:1 mixture of regioisomers $\mathbf{A}$ and $\mathbf{B}$ was observed (Table 1, entry 1). 


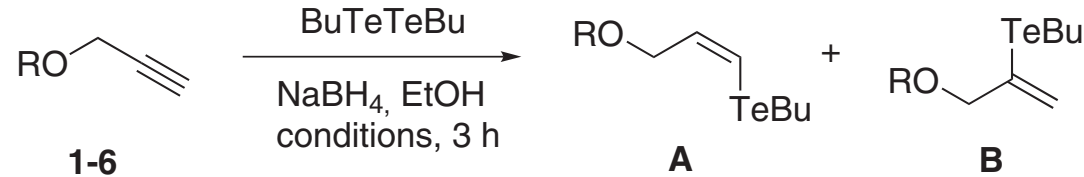

$\mathrm{R}=\mathrm{H}$, TBS, TIPS, TBPS, MEM, THP

Scheme 1.

a)

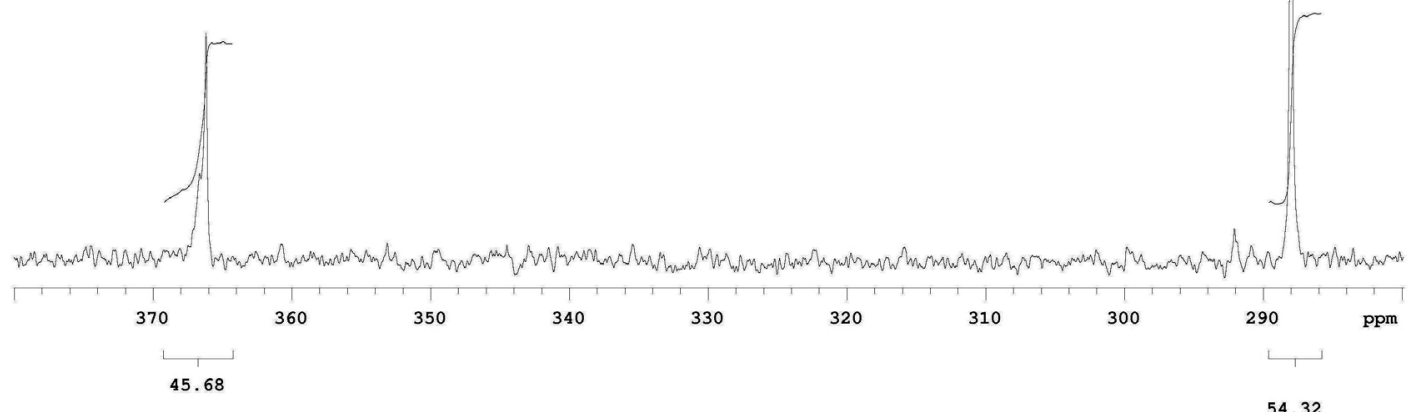

54.32

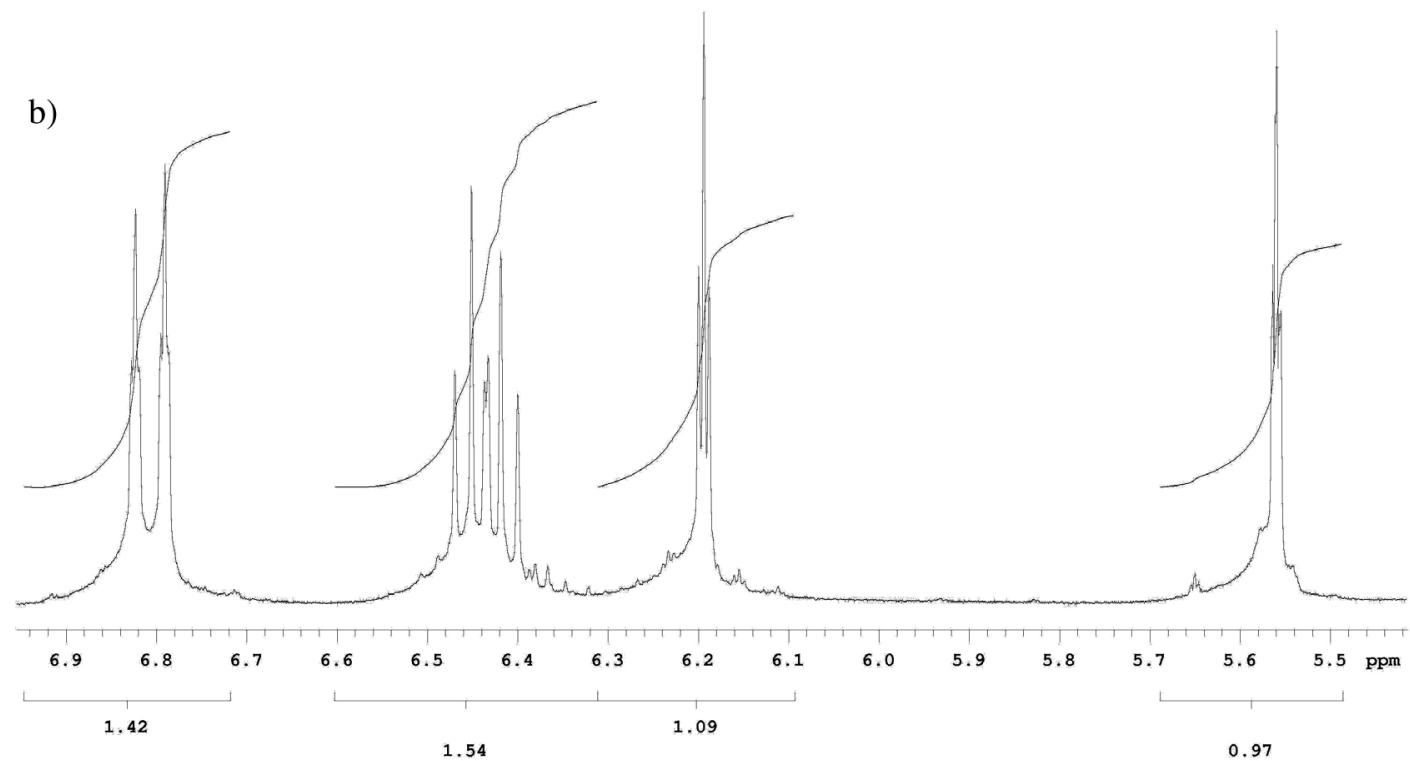

Figure 1. Vinyl telluride 1 (a) ${ }^{1} \mathrm{H}$ NMR (300 MHz, $\mathrm{CDCl}_{3}$, parts) and (b) ${ }^{125} \mathrm{Te} \mathrm{NMR}\left(94.6 \mathrm{MHz}, \mathrm{CDCl}_{3}\right.$ ) prepared according to Scheme 1 . The ratio of regioisomers $\mathbf{A}$ and $\mathbf{B}$ in both spectra is the same.

Table 1. Influence of temperature on the formation of vinyl tellurides $\mathbf{A}$ and $\mathbf{B}$ prepared via Scheme 1

\begin{tabular}{|c|c|c|c|c|c|c|}
\hline \multirow[t]{2}{*}{ Entry } & \multirow[t]{2}{*}{ Alkyne } & \multicolumn{2}{|c|}{$\mathbf{A}: \mathbf{B}$} & \multicolumn{2}{|c|}{$\delta(\mathrm{ppm}){ }^{125} \mathrm{Te}$ NMR $\left(\mathrm{CDCl}_{3}\right)$} & \multirow[t]{2}{*}{ Yield $(\%)^{\mathrm{a}}$} \\
\hline & & $25^{\circ} \mathrm{C}$ & $78^{\circ} \mathrm{C}$ & $\mathbf{A}$ & B & \\
\hline 1 & $\mathbf{1}, \mathrm{R}=\mathrm{H}$ & $56: 44$ & $56: 44$ & 287.9 & 366.1 & $72(78)$ \\
\hline 2 & $2, \mathrm{R}=\mathrm{TBS}$ & $70: 30$ & $85: 15$ & 292.9 & 378.6 & $89(90)$ \\
\hline 3 & $3, \mathrm{R}=\mathrm{TIPS}$ & $82: 18$ & $88: 12$ & 298.6 & 387.7 & $88(87)$ \\
\hline 4 & $\mathbf{4}, \mathrm{R}=\mathrm{TBDPS}$ & $-\mathrm{b}$ & $86: 14$ & 308.1 & 394.3 & $0(80)$ \\
\hline 5 & 5, R = MEM & $64: 36$ & $79: 21$ & 301.4 & 402.2 & $88(80)$ \\
\hline 6 & $6, \mathrm{R}=\mathrm{THP}$ & $55: 45$ & $76: 24$ & 305.9 & 400.1 & $85(87)$ \\
\hline
\end{tabular}

${ }^{\mathrm{a}} \mathrm{Chromatographic} \mathrm{yields} \mathrm{(the} \mathrm{yield} \mathrm{between} \mathrm{parenthesis} \mathrm{corresponds} \mathrm{to} \mathrm{the} \mathrm{reaction} \mathrm{at} 78{ }^{\circ} \mathrm{C}$ ); ${ }^{\mathrm{b}}$ Products not observed at this temperature. 
The influence of the protective group is remarkable. When bulky groups such as TBS and TIPS were used (Table 1, entries 2 and 3 ) better regioselectivities were observed. The THP and MEM ethers gave lower regioselectivities when compared with the silyl groups (Table 1, entries 4 and 5).

In spite of the widespread use of bulky groups in organic chemistry, there are few attempts at quantifying the intuitive concept of bulkiness. ${ }^{12}$ The screening action of a bulky group on an atom could be described by an angle. ${ }^{13}$ This concept of cone angle was applied to silyl groups and the cone angles found for TIPS, $\theta=160^{\circ}$, and TBS, $\theta=139^{\circ} .{ }^{14}$ In other words, the bulkiness of TIPS seems to be of the correct magnitude as to exhibit a good compromise between useful steric effects (rather than electronic factors) to give the desired regioisomer.

The influence of the temperature on the reaction was also studied. When the hydrotelluration reaction was performed at $0{ }^{\circ} \mathrm{C}$ the formation of the corresponding vinyl tellurides $\mathbf{A}$ and $\mathbf{B}$ was not observed for all substrates. This fact might be due to the lower reactivity of the involved species at this temperature. When the reaction was performed at $25^{\circ} \mathrm{C}$, under controlled conditions, the observed regioselectivities were lower if compared with the results obtained under reflux conditions.

The two regioisomeric tellurides $\mathbf{A}$ and $\mathbf{B}$ were obtained under different conditions, with vinyl telluride A predominating at higher temperature. This fact should indicate that the telluride $\mathbf{A}$ might be the thermodynamic product. Therefore, vinyl telluride $\mathbf{B}$ would be the kinetic product (or the product of kinetic control) since it should be formed faster at lower temperatures. To test this hypothesis, a 55:45 mixture of tellurides $\mathbf{A}$ and $\mathbf{B}$ were stirred in $\mathrm{EtOH}$ under reflux during $2 \mathrm{~h}$. No change in the ratio of the products was observed, even when an additional amount of sodium borohydride was added.

The effect of the distance of the hydroxyl moiety from the triple bond, as well as the influence of a substituted propargylic alcohol on the ratio of the products were also studied (Scheme 2). The results are depicted in Table 2.

Lower regioselectivities were observed for the unprotected alcohols (Table 2, entries 1 and 2). However, better regioselectivities were observed when TIPS was used (Table 2, entries 3 and 4). It is interesting to note that when 9 was used as the alkyne source; only one regioisomer was obtained (Table 2, entry 3 ).

The methodology was then applied for the diastereoselective synthesis of the double bond present in $( \pm$ )-Seselidiol (Figure 1) a natural product isolated in $0.0085 \%$ yield from the roots of Seseli mairei Wolff (Umbelliferae) and used as herbal remedies for human inflammation, swelling, rheumatism, pain, and common cold in folk Chinese medicine. ${ }^{15}$ It also showed significant cytotoxicity in KB, P-388, and L-1210 tumor cells $\left(\right.$ ED50 $\left.<10 \mu \mathrm{g} \mathrm{mL}^{-1}\right) .{ }^{16}$ The absolute stereochemistry of the stereogenic centers in Seselidiol is not known, and to date no total synthesis of the natural product has been attempted.

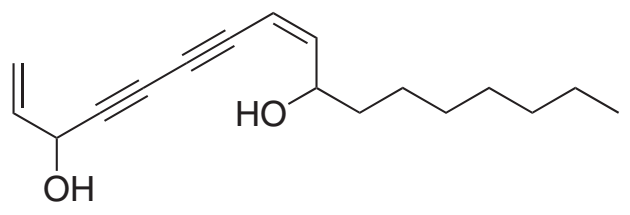

Figure 2. ( \pm )-Seselidiol

Our approach for the synthesis of Seselidiol started with 1-octanol 11 which was oxidized into the corresponding
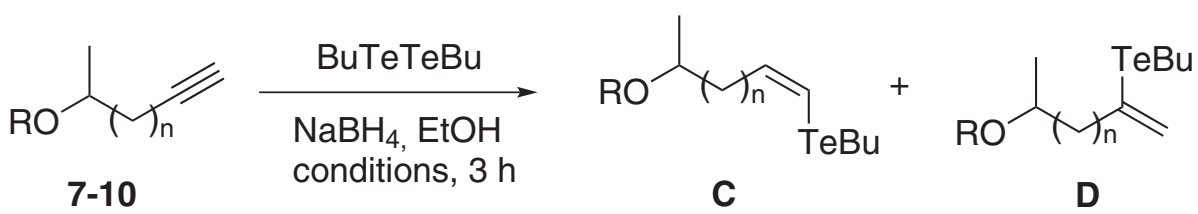

Scheme 2.

Table 2. Influence of temperature on the formation of vinyl tellurides prepared via Scheme 2

\begin{tabular}{|c|c|c|c|c|c|c|c|}
\hline \multirow[t]{2}{*}{ Entry } & \multirow[t]{2}{*}{ Alkyne } & \multirow[t]{2}{*}{$\mathrm{n}$} & \multicolumn{2}{|c|}{ C:D } & \multicolumn{2}{|c|}{$\delta(\mathrm{ppm}){ }^{125} \mathrm{Te} \mathrm{NMR}\left(\mathrm{CDCl}_{3}\right)$} & \multirow[t]{2}{*}{ Yield $(\%)^{\mathrm{a}}$} \\
\hline & & & $25^{\circ} \mathrm{C}$ & $78^{\circ} \mathrm{C}$ & $\mathbf{C}$ & D & \\
\hline 1 & 7, $\mathrm{R}=\mathrm{H}$ & 0 & $-\mathrm{b}$ & $77: 23$ & 301.9 & 338.3 & $0(70)$ \\
\hline 2 & $8, \mathrm{R}=\mathrm{H}$ & 1 & $-\mathrm{b}$ & $58: 42$ & 357.6 & 274.1 & $0(65)$ \\
\hline 3 & $\mathbf{9}, \mathrm{R}=\mathrm{TIPS}$ & 0 & $85: 15$ & 100:0 & 279.1 & - & $65(80)$ \\
\hline 4 & $\mathbf{1 0}, \mathrm{R}=\mathrm{TIPS}$ & 1 & $63: 37$ & $82: 18$ & 358.8 & 286.9 & $62(78)$ \\
\hline
\end{tabular}

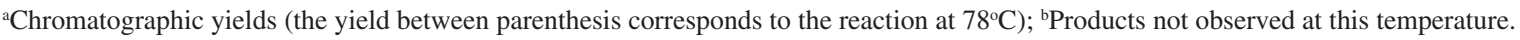




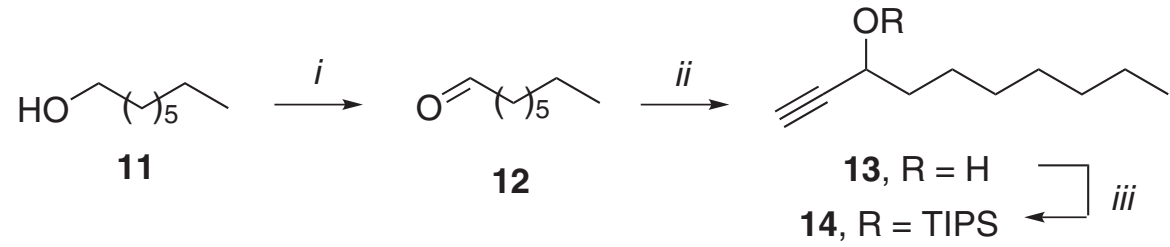

Scheme 3. (i) PCC, $\mathrm{CH}_{2} \mathrm{Cl}_{2}, 3 \mathrm{~h}, 0{ }^{\circ} \mathrm{C}(55 \%)$; (ii) ethynylmagnesium bromide, THF, $25^{\circ} \mathrm{C}, 12 \mathrm{~h}(50 \%)$; (iii) $\mathrm{TIPSCl}$, imidazole, DMF, $25^{\circ} \mathrm{C}, 12 \mathrm{~h}(85 \%)$.

14

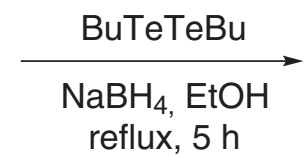

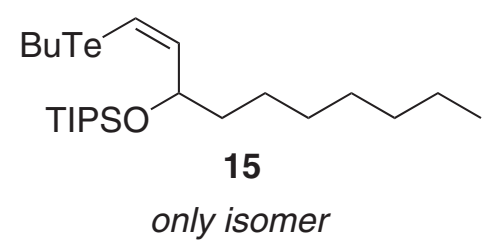

Scheme 4. aldehyde 12 using PCC. ${ }^{17}$ Addition of ethynylmagnesium bromide to 12 at room temperature ${ }^{18}$ gave alcohol 13 which was converted into its TIPS ether derivative $\mathbf{1 4}$ (Scheme 3).

Hydrotelluration of $\mathbf{1 4}$ using the developed methodology gave the corresponding $Z$-vinyl telluride $\mathbf{1 5}$ as a single isomer determined by ${ }^{1} \mathrm{H}$, and confirmed by ${ }^{125} \mathrm{Te} \mathrm{NMR}$ and gas chromatography in $90 \%$ yield (Scheme 4).

It is noteworthy that when the hydrotelluration reaction was performed without TIPS as the protective group a mixture of 78:22 of the two regioisomers were observed.

\section{Conclusions}

In summary, the methodology presented is shown to be useful for the synthesis of regio- and stereo-defined vinyl tellurides, the TIPS group being successfully used as a regio-directing group. The application of the methodology to the synthesis of a natural product was performed in order to demonstrate its applicability. Finally, the methodology offers future possibilities in the development of new organometallic approaches to the compounds containing $Z$-double bonds. The completion of the synthesis of $( \pm)$-Seselidiol and its asymmetric version are ongoing in our laboratory and will be reported in a due course.

\section{Acknowledgments}

The authors gratefully acknowledge $\mathrm{CNPq}$ and FACEPE for financial support. The authors also thank to CNPq for their fellowships.

\section{Supplementary Information}

Supplementary information, with extra experimental and characterization data, is available free of charge at http://jbcs.sbq.org.br, as PDF file.

\section{References}

1. Eisch, J. J. In Comprehensive Organic Synthesis; Trost, B. M., Fleming, I., eds.; Pergamon Press: Oxford, 1991, Vol. 8, p. 733; Pelter, A.; Smith, K.; Brown, H. C. In Borane Reagents; Academic Press: London, 1988; Smith, K.; Pelter, A. In Comprehensive Organic Synthesis; Trost, B. M., Fleming, I., eds.; Pergamon Press: Oxford, 1991, Vol. 8, p. 703; Schwartz, J.; Labinger, J. A.; Angew. Chem., Int. Ed. 1976, 15, 333; Labinger, J. A. In Comprehensive Organic Synthesis; Trost, B. M., Fleming, I., eds.; Pergamon Press: Oxford, 1991, Vol. 8, p. 667.

2. Zeni, G.; Lüdtke, D. S.; Panatieri, R. B.; Braga, A. L.; Chem. Rev. 2006, 106, 1032; Nogueira, C. W.; Zeni, G.; Rocha, J. B. T.; Chem. Rev. 2004, 104, 6255.

3. Johnson, R. A.; Sharpless, K. B. In Comprehensive Organic Synthesis; Pergamon Press: Oxford, UK, 1990, Vol. 7; Finn, M. G.; Sharpless, K. B. In Asymmetric Synthesis; Morrison, J. D., ed.; Academic Press: New York, 1985, Vol. 5; Burns, C. J.; Martin, C. A.; Sharpless, K. B.; J. Org. Chem. 1989, 54, 2826.

4. Stefani, H. A.; Cardoso, L. D. G.; Valduga, C. J.; Zeni, G.; Phosphorus, Sulfur Silicon Relat. Elem. 2001, 171, 421; Perin, G.; Jacob, R. G.; Dutra, L. G.; de Azambuja, F.; Dos Santos, G. F. F.; Lenardão, E. J.; Tetrahedron Lett. 2006, 47, 935.

5. Raminelli, C.; Da Silva, N. C.; Dos Santos, A. A.; Porto, A. L. M.; Andrade, L. H.; Comasseto, J. V.; Tetrahedron 2005, 61, 409.

6. Chaudhary, S. K.; Hernandez, O.; Tetrahedron Lett. 1979, 20, 99; Bennett, F.; Knight, D. W.; Fenton, G.; J. Chem. Soc. Perkin Trans. 1 1991, 1543.

7. Cunico, R. F.; Bedell, L.; J. Org. Chem. 1980, 45, 4797.

8. Nicolaou, K. C.; Pavia, M. R.; Seitz, S. P.; J. Am. Chem. Soc. 1981, 103, 1224.

9. Kremers, J. A.; Meijer, E. W. J. Org. Chem. 1994, 59, 4262.

10. Miyashita, M.; Yoshikoshi, A.; Grieco, P. A.; J. Org. Chem. 1977, 42, 3772. 
11. Barros, S. M.; Dabdoub, M. J.; Dabdoub, V. M. B.; Comasseto, J. V.; Organometallics 1989, 8, 1661; Zeni, G.; Formiga, H. B.; Comasseto, J. V.; Tetrahedron Lett. 2000, 41, 1311.

12. Ruecker, C.; Chem. Rev. 1995, 95, 1009.

13. Tolman, C. A.; Chem. Rev. 1977, 77, 313; Imyanitov, N. S.; Sov. J. Coord. Chem. Engl. Transl. 1985, 11, 663.

14. Panek, J. S.; Prock, A.; Eriks, K; Giering, W. P.; Organometallics 1990, 9, 2175.

15. "Chung Yao Ta Tsu Dim" (Dictionary of Chinese Medicine), Shanghai Science and Technology Publishing Co., 1978, Vol. 1,909 .
16. Hu, C-Q.; Chang, J-J.; Lee, K-H.; J. Nat. Prod. 1990, 53, 932. 17. Piancatelli, G.; Scettri, A.; D’Auria, M.; Synthesis 1982, 245; Kasmai, H. S.; Mischke, S. G.; Blake, T. J.; J. Org. Chem. 1995, 60, 2267.

18. Skattebol, L.; Jones, E. R. H.; Whiting, M. C.; Org. Synth. 1959, 39, 56; Rinaldi, P. L.; Levy, G. C.; J. Org. Chem. 1980, 45,4348 .

Received: June 17, 2009

Web Release Date: November 26, 2009

FAPESP helped in meeting the publication costs of this article. 


\title{
Influence of Different Protecting Groups on the Regioselectivity of the Hydrotelluration Reaction of Hydroxy Alkynes
}

\author{
Juliana M. Oliveira, ${ }^{a}$ Dayvson J. Palmeira, ${ }^{a}$ João V. Comasseto ${ }^{b}$ and Paulo H. Menezes ${ }^{* a}$ \\ ${ }^{a}$ Departamento de Química Fundamental, Universidade Federal de Pernambuco, CCEN, UFPE, \\ Av. Prof. Luiz Freire, s/n, 50670-901 Recife-PE, Brazil
}

${ }^{b}$ Instituto de Química, Universidade de São Paulo, USP, Av. Prof. Lineu Prestes, 748, 05508-900 São Paulo-SP, Brazil

\section{GENERAL REMARKS}

All reactions were conducted in flame dried glassware under nitrogen. All solvents were purified before use. THF was dried by distillation from sodium benzophenone ketyl. $\mathrm{CH}_{2} \mathrm{Cl}_{2}$ and DMF were dried by distillation from $\mathrm{CaH}_{2}$. All other commercially available reagents and solvents were used as received.

${ }^{1} \mathrm{H}$ NMR data were recorded at $300 \mathrm{MHz}$ using a Varian UNITY PLUS spectrometer. ${ }^{1} \mathrm{H}$ NMR chemical shifts are reported as delta $(\delta)$ units in parts per million (ppm) relative to residual $\mathrm{CHCl}_{3}(7.26 \mathrm{ppm})$. Coupling constants $(J)$ were reported in Hertz $(\mathrm{Hz}) .{ }^{13} \mathrm{C}$ NMR data were recorded at $75 \mathrm{MHz}$ using a Varian UNITY PLUS spectrometer. ${ }^{13} \mathrm{C}$ NMR chemical shifts were reported as delta $(\delta)$ units in parts per million (ppm) relative to the central line of $\mathrm{CDCl}_{3}(77.0 \mathrm{ppm}) .{ }^{125} \mathrm{Te}$ NMR data were obtained at $94.6 \mathrm{MHz}$ using diphenyl ditelluride as an external reference $(422.0 \mathrm{ppm})$. Typical parameters were as follows: acquisition time equal to 0.64 second, pulse of $45^{\circ}$, spectral window of $43.9 \mathrm{kHz}$; and line broadening equal to $5.0 \mathrm{~Hz}$; a good compromise value because although a greater line broadening would improve the signal-to-noise ratio of the tellurium spectra, which would also imply in less signal resolution.

Low resolution mass spectra were obtained using a Shimadzu QP-5050a Spectometer $(70 \mathrm{eV})$ using helium 4.5 as a carrier gas and a DB-5 column $(30 \mathrm{~m} \times 0.25 \mu \mathrm{m})$.

Reactions were monitored by thin-layer chromatography on $0.25 \mathrm{~mm}$ E. Merck silica gel 60 plates (F254) using UV light and vanillin as visualizing agents. Column chromatographic purifications were performed using Silica Gel 60 (230 - 400 mesh) unless indicated otherwise. ${ }^{1}$ All compounds purified by chromatography were sufficiently

*e-mail: pmenezes@ufpe.br pure for use in further experiments, unless indicated otherwise.

Dibutylditelluride (BuTeTeBu) $)^{11}$

A $2 \mathrm{~L}$ round-bottomed flask was flamed dry and equipped with a $250 \mathrm{~mL}$ pressure equalized dropping funnel. Tellurium metal $\left(40.2 \mathrm{~g}, 315 \mathrm{mmol}\right.$, dried at $85^{\circ} \mathrm{C}$ prior to use in an oven) was suspended in dry THF $(1 \mathrm{~L})$ and cooled to $0{ }^{\circ} \mathrm{C}$. The addition funnel was charged with $n$-butyllithium ( $360 \mathrm{mmol}, 144 \mathrm{~mL}$ of a $2.5 \mathrm{~mol} \mathrm{~L}^{-1}$ solution in hexanes). The $n$-butyllithium was added dropwise. After the addition was complete, the ice bath was removed and the reaction mixture was stirred at room temperature for $60 \mathrm{~min}$. A saturated solution of ammonium chloride $(450 \mathrm{~mL})$ was then added slowly. The reaction was stirred at room temperature for about $3 \mathrm{~h}$ while open to the atmosphere $\left(\mathrm{O}_{2}\right)$. The organic layer was isolated and the aqueous layer was extracted with ethyl acetate $(1 \times 300 \mathrm{~mL})$. The combined organic phases were dried over anhydrous magnesium sulfate and filtered through a pad of Celite. Concentration in vacuo provided $50.7 \mathrm{~g} \mathrm{(87 \% )}$ of dibutylditelluride as a red oil which was used directly without further purification. ${ }^{1} \mathrm{H} \mathrm{NMR}\left(300 \mathrm{MHz}, \mathrm{CDCl}_{3}\right)$ $\delta 3.10(t, J 7.80 \mathrm{~Hz}, 2 \mathrm{H}), 1.80-1.60(m, 2 \mathrm{H}), 1.46-1.30\left(m^{3}\right.$, $2 \mathrm{H}), 0.92(t, J 7.50 \mathrm{~Hz}, 3 \mathrm{H}) .{ }^{13} \mathrm{C} \mathrm{NMR}(75 \mathrm{MHz}, \mathrm{CDCl})$ $\delta 35.6 ; 24.5 ; 13.3 ; 4.21$. IR (film) $v_{\max } / \mathrm{cm}^{-1}: 2955,2921^{3}$, $2868,1457,1175$.

General Procedure for Protection of Propargyl Alcohol with $\mathrm{R}_{3} \mathrm{SiCl}$

To a round-bottomed flask under argon was added DMF $(2 \mathrm{~mL})$, imidazole $(1.70 \mathrm{~g}, 25 \mathrm{mmol})$, and propargyl alcohol

${ }^{1}$ Still, W. C.; Kahn, M.; Mitra, A.; J. Org. Chem. 1978, 43, 2923. 
$(0.56 \mathrm{~g}, 0.58 \mathrm{~mL}, 10 \mathrm{mmol})$. The mixture was stirred and $\mathrm{R}_{3} \mathrm{SiCl}$ [TBSCl, TIPSCl, TBDPSCl] (12 mmol) was slowly added. The mixture was stirred for $12 \mathrm{~h}$, diluted with $\mathrm{CH}_{2} \mathrm{Cl}_{2}(20 \mathrm{~mL})$ and quenched with water $(20 \mathrm{~mL})$. The organic phase was washed with $3 \% \mathrm{HCl}(10 \mathrm{~mL})$, saturated $\mathrm{NaHCO}_{3}(20 \mathrm{~mL})$ and finally water. The organic phase was then dried over $\mathrm{MgSO}_{4}$, filtered and concentrated in vacuo. The pure silyl ether was distilled from the residue under reduced pressure.

tert-butyldimethyl(prop-2-ynyloxy)silane (2)

$\left.1.64 \mathrm{~g} \mathrm{(65 \% );} \mathrm{(bp} 40{ }^{\circ} \mathrm{C}, 8 \mathrm{mmHg}\right)^{1} \mathrm{H}$ NMR $(300 \mathrm{MHz}$, $\left.\mathrm{CDCl}_{3}\right) \delta 4,20(d, J 1.8 \mathrm{~Hz}, 2 \mathrm{H}) ; 2,15(t, J 2,7 \mathrm{~Hz}, 1 \mathrm{H})$; $0,88-0,80(m, 9 \mathrm{H}) ; 0,13-0,10(m, 6 \mathrm{H}) .{ }^{13} \mathrm{C}$ NMR $(75 \mathrm{MHz}$, $\left.\mathrm{CDCl}_{3}\right) \delta 81.0 ; 73.88 ; 53.01 ; 26.07 ; 18.23 ;-5.1$.

triisopropyl(prop-2-ynyloxy)silane (3)

$\left.1.45 \mathrm{~g} \mathrm{(68 \% );} \mathrm{(bp} 110{ }^{\circ} \mathrm{C}, 20 \mathrm{mmHg}\right)^{1} \mathrm{H}$ NMR (300 $\left.\mathrm{MHz}, \mathrm{CDCl}_{3}\right) \delta 4,37(d, J 2,4 \mathrm{~Hz}, 2 \mathrm{H}) ; 2,38(t, J 2,7 \mathrm{~Hz}$, $1 \mathrm{H}) ; 1,11-1,04,(m, 21 \mathrm{H}) .{ }^{13} \mathrm{C} \mathrm{NMR}\left(75 \mathrm{MHz}, \mathrm{CDCl}_{3}\right) \delta$ $81.40 ; 72.58 ; 51.72 ; 17.85 ; 11.90$.

\section{tert-butyldiphenyl(prop-2-ynyloxy)silane (4)}

$1.37 \mathrm{~g} \mathrm{(50 \% );}{ }^{1} \mathrm{H}$ NMR (300 MHz, $\left.\mathrm{CDCl}_{3}\right)$ 7,80-7,35 $(m, 10 \mathrm{H}) ; 4,32(d, J 2,4 \mathrm{~Hz}, 2 \mathrm{H}) ; 2,39(t, J 2,1 \mathrm{~Hz}, 1 \mathrm{H})$; $1,07(s, 9 \mathrm{H}) .{ }^{13} \mathrm{C} \mathrm{NMR}\left(75 \mathrm{MHz}, \mathrm{CDCl}_{3}\right) \delta 135.54 ; 134.78$; $132.86 ; 129.54 ; 80.1 ; 73.02 ; 52.42 ; 26.08 ; 19.10$.

(but-3-yn-2-yloxy)triisopropylsilane (9)

$1.81 \mathrm{~g} \mathrm{(80 \% );}{ }^{1} \mathrm{H}$ NMR (300 MHz, $\left.\mathrm{CDCl}_{3}\right) 4.60(d q, J$ 6.5, $1.7 \mathrm{~Hz}, 1 \mathrm{H}) ; 2.38(d, J 2.4 \mathrm{~Hz}, 1 \mathrm{H}) ; 1.46(d, J 6.4 \mathrm{~Hz}$, $3 \mathrm{H}) ; 1,07(m, 21 \mathrm{H}) .{ }^{13} \mathrm{C} \mathrm{NMR}\left(75 \mathrm{MHz}, \mathrm{CDCl}_{3}\right) \delta 86.7$, $71.2,58.8,25.5,18.1,17.8,12.2$.

triisopropyl(pent-4-yn-2-yloxy)silane (10)

$1.90 \mathrm{~g}(80 \%) ;{ }^{1} \mathrm{H}$ NMR $\left(300 \mathrm{MHz}, \mathrm{CDCl}_{3}\right) \delta 4,07$ ( $m$, $1 \mathrm{H}) ; 2,96(d d, J 8.1 \mathrm{~Hz}, J 2.7 \mathrm{~Hz}, 2 \mathrm{H}) ; 1,98(t, J 2.7 \mathrm{~Hz}$, $1 \mathrm{H}) ; 1,29(d, J 5.7 \mathrm{~Hz}, 3 \mathrm{H}) ; 1,07(m, 21 \mathrm{H}) .{ }^{13} \mathrm{C}$ NMR $(75$ $\left.\mathrm{MHz}, \mathrm{CDCl}_{3}\right) \delta 82.2 ; 73.1 ; 68.6 ; 31.4 ; 24.4 ; 18.5 ; 13.1$.

\section{3-(2-methoxyethoxy)prop-1-yne (5)}

To a round-bottomed flask under argon was added diisopropylamine $(5.0 \mathrm{~mL}, 35.7 \mathrm{mmol})$ and propargyl alcohol $(0.84 \mathrm{~g}, 0.87 \mathrm{~mL}, 15 \mathrm{mmol})$. The mixture was stirred at room temperature and $\mathrm{MEMCl}(1.91 \mathrm{~mL}$, $16.8 \mathrm{mmol}$ ) was slowly added. The mixture was stirred for $12 \mathrm{~h}$, diluted with $\mathrm{CH}_{2} \mathrm{Cl}_{2}(20 \mathrm{~mL})$ and quenched with water $(20 \mathrm{~mL})$. The organic phase was washed with $3 \% \mathrm{HCl}$ $(10 \mathrm{~mL})$, saturated $\mathrm{NaHCO}_{3}(20 \mathrm{~mL})$ and finally water $(3 \times$ $20 \mathrm{~mL}$ ). The organic phase was then dried over $\mathrm{MgSO}_{4}$, filtered and concentrated in vacuo. The residue was distilled under reduced pressure (bp $100{ }^{\circ} \mathrm{C}, 15 \mathrm{mmHg}$ ) to yield $0.68 \mathrm{~g}(50 \%)$ of the title compound. ${ }^{1} \mathrm{H}$ NMR $(300 \mathrm{MHz}$, $\left.\mathrm{CDCl}_{3}\right) \delta 4,78(m, 2 \mathrm{H}) ; 4,22(d d, J 2.4 \mathrm{~Hz}, J 1.2 \mathrm{~Hz}, 2 \mathrm{H})$; $3,69(m, 2 \mathrm{H}) ; 3,53(m, 2 \mathrm{H}) ; 3,36(t, 3 \mathrm{H}) ; 2,41(d t, J 7.2 \mathrm{~Hz}$, $J 2.4 \mathrm{~Hz}, 1 \mathrm{H}) .{ }^{13} \mathrm{C}$ NMR $\left(75 \mathrm{MHz}, \mathrm{CDCl}_{3}\right) \delta 54.53 ; 58.93$; $66.69 ; 67.09 ; 74.52 ; 79.23 ; 95.55$.

\section{2-(prop-2-ynyloxy)tetrahydro-2H-pyran (6)}

To a round-bottomed flask under argon was added PPTS (0.29 g, $0.9 \mathrm{mmol})$, propargyl alcohol (0.56 g, $0.58 \mathrm{~mL}, 10 \mathrm{mmol})$ and $\mathrm{CH}_{2} \mathrm{Cl}_{2}(10 \mathrm{~mL})$. The mixture was stirred at room temperature and DHP $(1,40 \mathrm{~g}, 1.68$ $\mathrm{mL}, 10 \mathrm{mmol}$ ) was slowly added. The mixture was stirred for $3 \mathrm{~h}$, diluted with $\mathrm{CH}_{2} \mathrm{Cl}_{2}(20 \mathrm{~mL})$ and washed with water $(3 \times 20 \mathrm{~mL})$. The organic phase was then dried over $\mathrm{MgSO}_{4}$, filtered and concentrated in vacuo. The residue was distilled under reduced pressure $\left(\mathrm{bp} 80^{\circ} \mathrm{C}, 25 \mathrm{mmHg}\right.$ ) to yield 1.54 (85\%) of the title compound. ${ }^{1} \mathrm{H}$ NMR (300 $\left.\mathrm{MHz}, \mathrm{CDCl}_{3}\right) \delta 4,73-4,70(m, 1 \mathrm{H}) ; 4,26(d d, J 2.7 \mathrm{~Hz}, J$ $1.2 \mathrm{~Hz}, 2 \mathrm{H}) ; 3,65-3,60(m, 2 \mathrm{H}) ; 2,39(d t, J 7.2 \mathrm{~Hz}, J 2.4$ $\mathrm{Hz}, 1 \mathrm{H}) ; 1,62-1,60(m, 2 \mathrm{H}) ; 1,56-1,50(m, 4 \mathrm{H}) .{ }^{13} \mathrm{C}$ NMR $\left(75 \mathrm{MHz}, \mathrm{CDCl}_{3}\right) \delta 18.90 ; 25.33 ; 30.1 ; 53.88 ; 61.87$; $73.93 ; 79.68 ; 96.71$.

\section{Representative Procedure for the Hydrotelluration of Alkynes 1-10}

The appropriate alkyne $(0.5 \mathrm{mmol})$ and dibutylditelluride (90 mg, $0.25 \mathrm{mmol}$ ) were dissolved in absolute ethanol $(4.0 \mathrm{~mL})$ at room temperature. Finely powdered sodium borohydride ( $26 \mathrm{mg}, 0.7 \mathrm{mmol}$ ) was added in portions to the above solution. Additional sodium borohydride was added as necessary to maintain a yellow color (indicative of the butyltellurolate anion). The solution was heated to reflux for $5 \mathrm{~h}$ and cooled to room temperature. The reaction mixture was then poured into a saturated solution of sodium bicarbonate $(20 \mathrm{~mL})$ and diluted with EtOAc $(20 \mathrm{~mL})$. The organic layer was isolated and washed with water $(50 \mathrm{~mL})$ and brine $(50 \mathrm{~mL})$ before drying over anhydrous magnesium sulfate. The organic phase was filtered, concentrated in vacuo, and submitted to ${ }^{1} \mathrm{H}$ and ${ }^{125} \mathrm{Te}$ NMR analysis without further purification.

\section{Synthesis of 1-octanal (12)}

To a round-bottomed flask equipped with an addition funnel was added PCC (21.6 g, $100.2 \mathrm{mmol})$ and $\mathrm{CH}_{2} \mathrm{Cl}_{2}$ $(100 \mathrm{~mL})$. The solution was cooled to $0{ }^{\circ} \mathrm{C}$ and 1 -octanol (11) $(13 \mathrm{~g}, 100 \mathrm{mmol})$ was added dropwise over $1 \mathrm{~h}$. After this period, the bath was removed and the solution stirred for an additional period of $3 \mathrm{~h}$. The mixture was then filtered through a pad of Celite and the solvent was removed in vacuo. The residue was distilled under reduced 
pressure (bp $90{ }^{\circ} \mathrm{C}, 80 \mathrm{mmHg}$ ) to yield $10 \mathrm{~g}(78 \%)$ of the title compound as a colorless oil. The data of the obtained compound match with the literature.

Synthesis of (+/-)-dec-1-yn-3-ol (13)

To a round-bottomed flask under argon and equipped with an addition funnel was added magnesium turnings $(1.22 \mathrm{~g}, 51 \mathrm{mmol})$ and THF $(30 \mathrm{~mL})$. The mixture was stirred and 1-bromoethane $(5.45 \mathrm{~g}, 50 \mathrm{mmol})$ was slowly added. In another flask under argon containing THF (20 $\mathrm{mL}$ ) at $-78^{\circ} \mathrm{C}$ dry acetylene gas was introduced through a gas-inlet tube (which reaches the bottom of the flask and is bent at the outer end for downward delivery) over $0.5 \mathrm{~h}$ period. The reaction was warmed up to room temperature and the solution of ethylmagnesium bromide was transferred via canula to this flask. The mixture was then cooled to $0{ }^{\circ} \mathrm{C}$ and $\mathbf{1 2}(3.20 \mathrm{~g}, 25 \mathrm{mmol})$ was added over a $45 \mathrm{~min}$ period. The mixture was then stirred for an additional $12 \mathrm{~h}$ and after this period slowly quenched with saturated $\mathrm{NH}_{4} \mathrm{Cl}$. Ethyl ether $(100 \mathrm{~mL})$ was added and the organic phase was washed with saturated $\mathrm{NH}_{4} \mathrm{Cl}$. The aqueous phase was extracted with ethyl ether $(3 \mathrm{x}$ $100 \mathrm{~mL}$ ) and the combined organic phases were dried over $\mathrm{MgSO}_{4}$, filtered and concentrated in vacuo. The residue was distilled under reduced pressure (bp $105^{\circ} \mathrm{C}$, $0.5 \mathrm{mmHg}$ ) to yield $1.88 \mathrm{~g}(49 \%)$ of the title compound as a colorless oil. The data of the obtained compound match with the literature. ${ }^{2}$

Synthesis of (+/-)-(dec-1-yn-3-yloxy)triisopropylsilane (14)

To a round-bottomed flask under argon was added DMF $(1 \mathrm{~mL})$, imidazole $(0.17 \mathrm{~g}, 2.5 \mathrm{mmol})$, and $13(0.154 \mathrm{~g}$, $1 \mathrm{mmol})$ the mixture was stirred and TIPSCl $(0.23 \mathrm{~g}$, $1.2 \mathrm{mmol}$ ) was slowly added. The mixture was stirred for $24 \mathrm{~h}$, diluted with $\mathrm{CH}_{2} \mathrm{Cl}_{2}(20 \mathrm{~mL})$ and quenched with water $(20 \mathrm{~mL})$. The organic phase was washed with $3 \%$ $\mathrm{HCl}(10 \mathrm{~mL})$, saturated $\mathrm{NaHCO}_{3}(20 \mathrm{~mL})$ and finally water. The organic phase was then dried over $\mathrm{MgSO}_{4}$, filtered and concentrated in vacuo. The residue was purified by silica gel chromatography (hexanes) to yield $0.27 \mathrm{~g}(88 \%)$ of the title compound. ${ }^{1} \mathrm{H}$ NMR ( $\left.300 \mathrm{MHz}, \mathrm{CDCl}_{3}\right) \delta 4,54$ $(t d, J 4.5 \mathrm{~Hz}, J 2.1,1 \mathrm{H}) ; 2,33(d, J 2.1 \mathrm{~Hz}, 1 \mathrm{H}) ; 1,71(q, J$ $7.5 \mathrm{~Hz}, J 4.5 \mathrm{~Hz}, 2 \mathrm{H}) ; 1,45-1,20(m, 10 \mathrm{H}) ; 1,10(m, 21 \mathrm{H})$; $0,90(t, 3 \mathrm{H}) .{ }^{13} \mathrm{C}$ NMR $\left(75 \mathrm{MHz}, \mathrm{CDCl}_{3}\right) \delta 84.43 ; 72.65$; $65.42 ; 46.96 ; 29.66 ; 28.72 ; 26.90 ; 23.05 ; 22.15 ; 17.81$; 14.09; 12.27. GC/MS m/z (rel. Int. \%) 267 (100); 225 (8) 211 (10); 169 (81); 157 (9); 131 (39); 103 (46); 75 (34); 61 (17); 59 (13); 57 (9); 43 (8); 41 (9).

Synthesis of (+/-)-(Z)-(1-(butyltellanyl)dec-1-en-3-yloxy) triisopropylsilane (15)

Compound $14(0.31 \mathrm{~g}, 1 \mathrm{mmol})$ and dibutylditelluride $(0.18 \mathrm{~g}, 0.5 \mathrm{mmol})$ were dissolved in degassed ethanol $(5.0 \mathrm{~mL})$ at room temperature. Finely powdered sodium borohydride (53 mg, $1.4 \mathrm{mmol}$ ) was added in portions to the above solution. Additional sodium borohydride was added as necessary to maintain a yellow color (indicative of the butyltellurolate anion). The solution was heated to reflux for $12 \mathrm{~h}$ and cooled to room temperature. The reaction mixture was then poured into a saturated solution of sodium bicarbonate $(30 \mathrm{~mL})$ and diluted with EtOAc $(20 \mathrm{~mL})$. The organic layer was isolated and washed with water $(50 \mathrm{~mL})$ and brine $(50 \mathrm{~mL})$ before drying over anhydrous magnesium sulfate. The organic phase was filtered, concentrated in vасио. The residue was purified by silica gel chromatography (hexanes) to yield $0.44 \mathrm{~g}$ (90\%) of the title compound. ${ }^{1} \mathrm{H}$ NMR $\left(300 \mathrm{MHz}, \mathrm{CDCl}_{3}\right)$ $\delta 6.62(d, J 9.6 \mathrm{~Hz}, 1 \mathrm{H}) ; 6.23(d t J 9.6 \mathrm{~Hz}, J 1.8 \mathrm{~Hz}, 1 \mathrm{H})$; $4.22-4.16(m, 1 \mathrm{H}) ; 2.71-2.58(m, 2 \mathrm{H}), 1,80-1,68(m, 2 \mathrm{H})$, $1,44-1.34(m, 2 \mathrm{H}), 1.44-1.27(m, 10 \mathrm{H}), 1.35-1.25(m, 2 \mathrm{H})$, $1.20-1.00(m, 21 \mathrm{H}), 0,95-0.85(m, 6 \mathrm{H}) .{ }^{13} \mathrm{C}$ NMR $(75 \mathrm{MHz}$, $\left.\mathrm{CDCl}_{3}\right) 143.53 ; 101.49 ; 75.73 ; 38.00 ; 34.09 ; 31.82 ; 29.79$; $24.90 ; 24.86 ; 22.65 ; 18.11 ; 14.10 ; 13.40 ; 12.36 ; 7.03 .{ }^{125} \mathrm{Te}$ NMR (94.6 MHz, $\mathrm{CDCl}_{3}$ ) 274.3. GC/MS m/z (rel. Int. \%) $498\left(\mathrm{M}^{+}\right)$(5); 455 (17); 397 (9); 323 (5); 311 (11); 267 (100); 157 (15); 131 (32); 115 (30); 103 (29); 95 (25); 87 (28); 81 (31); 75 (79); 73 (41); 67(35); 61 (50); 59 (66); 57 (52); 55 (39); 45 (16); 43 (35); 41 (60).

\footnotetext{
${ }^{2}$ Skattebol, L.; Jones, E. R. H.; Whiting, M. Org. Syn. 1963, 4, 793; Rinaldi, P. L.; Levy, G. C.; J. Org. Chem. 1980, 45 , 4348.
} 